\title{
Implementation of Private Television Policy Based on Broadcasting Regulation: Case Study of Malang City Local Program
}

\author{
Riski Amalia ${ }^{1}$, Reza Safitri ${ }^{2}$, Bambang Dwi Prasetyo ${ }^{3}$ \\ 1,2,3 Universitas Brawijaya, Malang, Indonesia \\ Email: riskiamalia@student.ub.ac.id
}

\begin{abstract}
It has been 18 years since the enactment of Law of The Republic of Indonesia Number 32 of 2002 on Broadcasting in Indonesia. During that time, Sistem Siaran Jaringan or commonly known as SSJ became the national broadcasting system. One of the elements in SSJ that differentiates it from the previous broadcasting system is the obligation for private broadcasters in Indonesia to broadcast local programs as much as $10 \%$ of their total broadcast hours. The hopes of Law of The Republic of Indonesia Number 32 of 2002 on Broadcasting, diversity of content and diversity of ownership, are often echoed in research related to broadcasting activities as a "revolution" from the previous broadcasting law which had the impression of being centralized from Jakarta. How are things now? Has this objective been implemented properly by private broadcaster in its broadcasting activities in Malang City?.
\end{abstract}

Keywords: SSJ, Media Democracy, Local Program, Broadcasting, Malang.

\section{A. INTRODUCTION}

The concept of democracy has a broad and complex meaning. As a political method, democracy is a political mechanism in choosing a leader (Lechmann in Nugroho, 2015, p. 2). Mass communication media is a democratic liaison network, a network that provides information and influence from the DPR and the general public as a reciprocal relationship (Mughan \& Dumitrescu, 2010, p. 477). The media play an important role in monitoring, nurturing and expanding the concept of democracy. In a democracy, the media is expected to encourage transparency and accountability in the implementation of government, as well as being able to become the eyes and ears of citizens. Although the press is traditionally regarded as a watchdog or supervisor of media democracy, other media in the form of public broadcasting, community media, and forms of internet-based use of information technology also have similar contributions and roles (Littlejohn \& Foss, 2009, p. 627). The key idea of media democracy emerged from the concentration of media ownership in recent decades in the hands of a few companies and individuals which has led to a narrowing of the range of voices and opinions expressed to the mass media (Malik, 2009, p. 6).

One of the efforts to build democracy is to democratize the media as a form of effort to guarantee and uphold the independence and freedom of expression, opinion, and freedom of the press. In addition, it also enforces the principles of diversity of ownership and diversity of content, as well as distributing information 
in a targeted manner and according to the audience (Siregar, 2014, p. xxviii). Democratization refers to the process of social change that is brought about in context and based on local needs and requirements. Media democratization refers to the reform of the existing media, the creation of an accountable and balanced media sector, and the use of media to bring about progressive social change. A balanced media sector is reflected in the provision for equal space in various types of media (both commercial, public and community) as well as the existence of laws that limit monopoly and the possibility of diversity (Littlejohn \& Foss, 2009, p. 628).

In Indonesia itself, positive developments for the democratization of the media in Indonesia emerged during the fall of Suharto in 1998. There was a massive deregulation that changed the landscape of the media in Indonesia dramatically. More than 1200 new print media emerged, more than 900 new radio commercials, and five new commercial television licenses were issued between 1998 and 2002 (Lim, 2011, p. 10). The public formed a media coalition and held a campaign to support the Press Law no. 40 of 1999 and the Broadcasting Law No. 32 of 2002. The Broadcasting Law No. 32 of 2002 emphasizes media decentralization and carries out the expectations of media democratization in the broadcasting sector in Indonesia (Lim, 2011, p. 21).

According to KPI (2017) there are two spirits born from Law of The Republic of Indonesia Number 32 of 2002 on Broadcasting, namely first, the management of the broadcasting system must be free from various interests because broadcasting is a public domain and is used as much as possible for the public interest. The second is the spirit to strengthen local entities in the spirit of regional autonomy by implementing a networked broadcast system. The principle of regional autonomy means that there is the granting of authority to regulate and manage all government affairs in the regions, outside the authority of the central government. Regions in Indonesia have the authority to make policies in services, increase participation, empower communities with the aim of increasing people's welfare (Kurniawan, 2010 , p. 422). In line with the principle of regional autonomy, the system that is considered appropriate for Indonesia is a broadcasting system based on networked television stations and local stations (Siregar, 2014, p. 154). For this reason, in Article 6 paragraph 3 of Law of The Republic of Indonesia Number 32 of 2002 on Broadcasting, it is written that "In the national broadcasting system there are broadcasting institutions and a fair and integrated network pattern which is developed by establishing network stations and local stations.". It is added with an explanation of the article, which reads: "What is meant by a fair and integrated network pattern is a reflection of the balance of information between regions and between regions and the center.". If the networked broadcasting system is successfully implemented in Indonesia, then in each broadcast area there will be many local television stations network members who will be able to carry out political, economic, and cultural functions for the people in their respective regions (Armando, 2019, p. 42). 
However, broadcasting itself is an industry. Most of the media consumed by society is created by businesses aiming to make money and it is undeniable that the media industry is a very profitable form of business (Havens \& Lotz, 2017, p. 2). Because it has such profitable potential, naturally business actors will emerge which then form the media industry, one of which is the television industry. Since the emergence of RCTI as the first television commercial in Indonesia in 1987 (Armando, 2016, p. 149), it has not taken long for business actors to create a media market. The media business is growing rapidly to date. Since RCTI started its business in 1989, its advertising expenditure reached Rp. 29 billion and continues to increase from year to year followed by other private televisions that emerged after that (Armando, 2011). Indonesia was once the highest in Asia's net advertising revenue, with the largest number from the television industry (Y. Nugroho et al., 2012, p. 36). Unfortunately, from the start, the privatization of broadcasting in Indonesia was not initiated by the government, but came from the initiative of local entrepreneurs who have access to the president (Armando, 2016). Broadcasting regulations were first enacted in the form of Broadcasting Law No. 24 of 1997 which was filled with strengthening the position of the television private sector. Which then revised and produced Law of The Republic of Indonesia Number 32 of 2002 on Broadcasting which is valid until now.

Regulation in the television industry is needed considering that television has considerable power in conveying audio-visual messages to the wider community. Regulations given by any government; laws and policies that are used to achieve a number of national interests and social policy goals (Albarran, 2010). Many researches related to broadcast regulation in Indonesia have been carried out. What has been in the spotlight in recent years is about media ownership and the diversity of media content, especially television. This study wants to take the smallest portion of broadcasting in the form of the obligation of each private broadcaster in broadcasting local programs in the applicable national broadcast system. Local programs are considered important because regulation is one form of representation of regions in Indonesia in broadcasting in Indonesia. Through this research, it will also be seen how private broadcaster in Malang City implements the policy, which can indirectly provide an overview of how the position of broadcast industry players and regulations in practice in Indonesia.

\section{B. METHOD}

The type of research used in this research is a case study with a qualitative approach. Case studies with a qualitative approach allow researchers to explore reallife, contemporary bound systems (cases) or multiple bound systems (cases) over time, through detailed and in-depth data collection involving multiple sources of information (e.g., observation, interviews, audiovisual materials, as well as documents, reports) (Creswell \& Poth, 2018). Data analysis in qualitative research involves several components. The data analysis process involves understanding the text and image data. This includes preparing the data for analysis, performing 
several different analyses, deepening understanding of the data, representing the data, and making broader interpretations of the meaning of the data itself (Creswell, 2009).

This study begins with initial observations and brief interviews with the East Java KPID. Initial observations are in the form of observations to find out which private broadcaster broadcasts local programs and the broadcast schedule because the shows to be recorded are terrestrial broadcasts that cannot be repeated. After the local program broadcast schedule for each private broadcaster was known, the researchers started to set up a USB tuner with an antenna and connected it to a computer to get the required UHF. The application starts and the documentation system starts. The recording schedule is for four weeks for each private broadcaster, starting from August 31, 2020 to November 8, 2020 during the broadcast hours of local programs for six private broadcaster, namely RCTI, ANTV, Metro TV, Net TV, RTV, and Kompas TV.

Documents used as references in this research include:

1. Law of The Republic of Indonesia Number 32 of 2002 on Broadcasting

2. Regulation of the Indonesian Broadcasting Commission Number 01/P/KPI/03/2012 concerning Guidelines for Broadcasting Conduct

3. Regulation of the Indonesian Broadcasting Commission Number 02/P/KPI/03/2012 concerning Broadcast Program Standards

4. Government Regulation of the Republic of Indonesia Number 50 of 2005 concerning Implementation of Private Broadcasting Institutions

5. Regulation of the Minister of Communication and Information Number 5 of 2018 concerning Reporting on Changes in Licensing Data, Permit Fees, Network Station Systems, and Economically Developed Regions and Economically Less Developed Regions in Broadcasting Operation.

Researchers categorize and share information based on applicable regulations. The researcher divides the categories into the overall duration of the show, the coverage area, and the graphic component that indicates the local program of each private broadcaster. In addition, researchers also compiled the provisions contained in the regulation in detail to be compared with their application in the field. Researchers re-compile regulations to obtain clear and directed information to obtain information about how the government wants the public to understand broadcasting regulations.

The next step is to compare the arrangement of these regulations with data that has been obtained from local program documentation from private broadcaster terrestrial broadcasts in Malang City. The need for this comparison is to be able to find out the pattern of private broadcaster in Malang City in implementing existing regulations in broadcasting regulations. After the pattern is obtained, the researcher can begin to interpret what is meant by regulation and how private broadcasters in Malang City interpret these regulations in local program broadcasting activities. Finally, researchers will get a pattern of local program broadcasting from private broadcaster which broadcasts in Malang City. From this pattern, researchers can see 
what private broadcaster understands and whether this understanding is in accordance with the wishes of government regulations on broadcasting. Or should the regulation itself actually need to be changed because private broadcaster has not implemented it effectively?

\section{RESULT AND DISCUSSION}

This discussion will be divided into four parts of the local program provisions in the regulation, namely: daily broadcast portion, broadcast time, information content about local areas, and broadcast programs. The first part that will be discussed is related to the provisions for the daily broadcast portion of local programs. There are two regulations that discuss this matter, namely:

Local broadcast programs must be produced and broadcast with a duration of at least $10 \%$ (ten percent) for television and at least $60 \%$ (sixty percent) for radio of the entire networked broadcast time per day (Indonesian Broadcasting Commission Regulation Number 02/P/ KPI/03/2012 concerning Broadcast Program Standards article 68 paragraph 1).

Broadcast programs relayed by network station members from the main network station are limited to a maximum duration of $40 \%$ (forty percent) for private radio broadcasting service and $90 \%$ (ninety percent) for private television broadcasting service of the entire broadcast time per day for station members network (Regulation of the Minister of Communication and Information Technology Number 5 of 2018 concerning Reporting of Changes in Licensing Data, License Fees, Network Station Systems, and Economically Developed Regions and Less Developed Economic Areas in Broadcasting Article 40 paragraph 1).

Network station members must load local broadcasts with a duration of at least $60 \%$ (sixty percent) for private radio broadcasting services and $10 \%$ (ten percent) for private television broadcasting services for the entire broadcast time per day (Regulation of the Minister of Communication and Information Number 5 years). 2018 concerning Reporting of Changes in Licensing Data, Permit Fees, Network Station Systems, and Economically Developed Regions and Economically Less Developed Regions in Broadcasting Article 40 paragraph 2). 


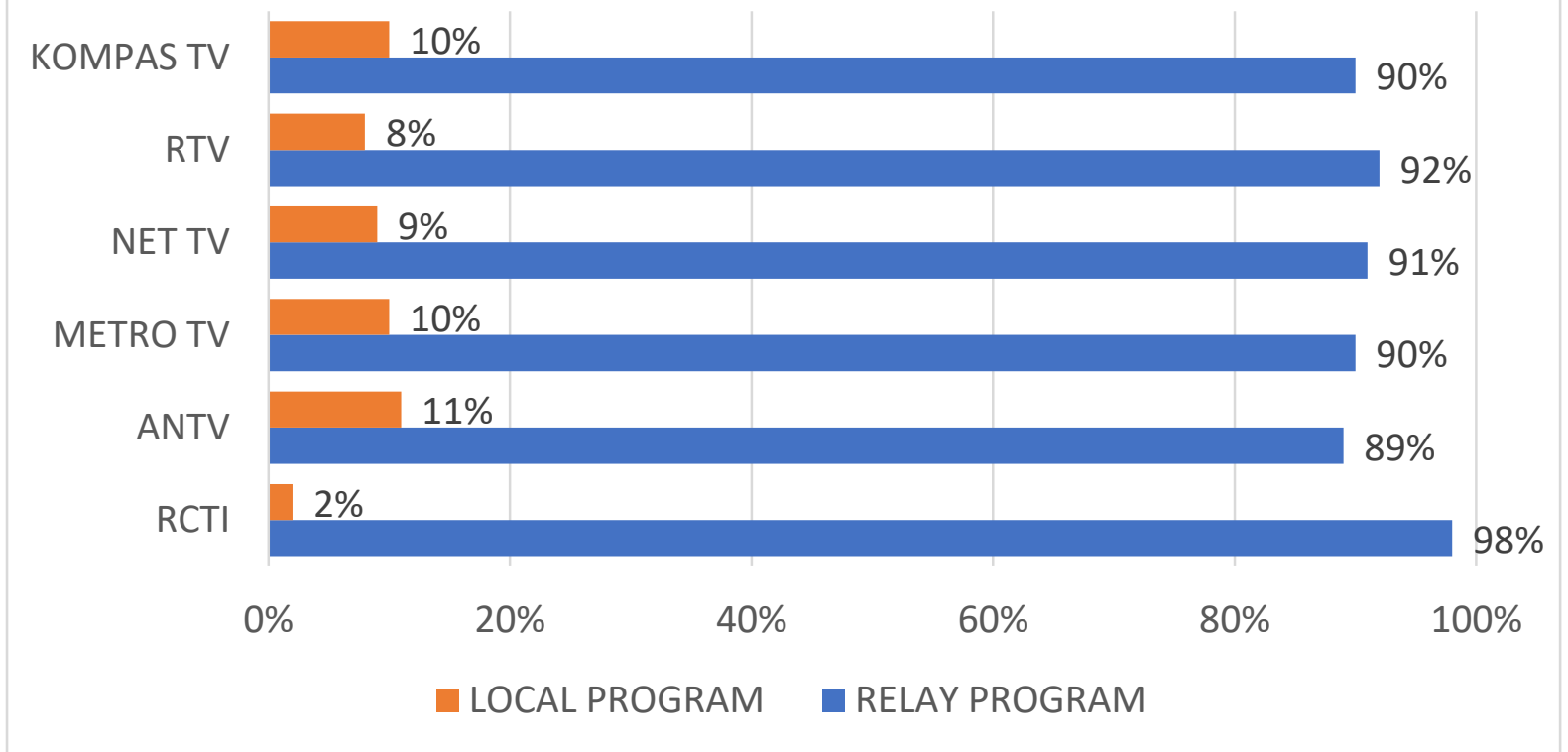

\section{Graph 1. Portion of Malang City Private Broadcaster Daily Broadcasts, from Researcher Processed Data (2020)}

Broadcasting of local programs must be broadcast with a duration of at least $10 \%$ of the total duration of the broadcast. From the data obtained, Kompas TV and ANTV fulfill $10 \%$ of local program broadcasts in one day. Metro TV meets the $10 \%$ requirement from Monday to Friday, while on Friday it only fulfills 6\%, and on Sundays it doesn't broadcast any local programs at all. Net TV and RTV meet 7\% and $9 \%$ of local program broadcasting requirements. Lastly, RCTI only fulfills $2 \%$ broadcast on Monday, Tuesday, Wednesday and does not broadcast locally on Thursday, Friday, Saturday, Sunday. Next, the researcher will discuss about the broadcast time of local programs.

Local broadcast programs as referred to in paragraph (1) above are at least $30 \%$ (thirty percent) of which must be broadcast at prime time local time (Indonesian Broadcasting Commission Regulation Number 02/P/KPI/03/2012 concerning Standard Broadcast Program article 68 paragraph 2).

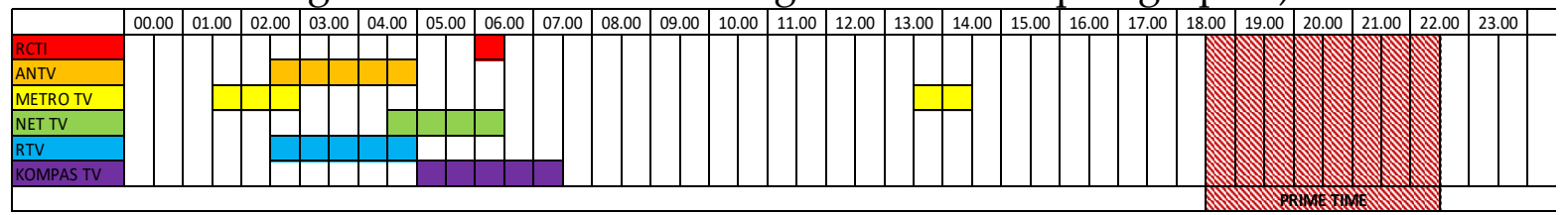

Figure 1. Illustration of Local Program Showtime Patterns, from Researcher

\section{Processed Data (2020)}

There are several opinions regarding the time mentioned as prime time. Some have seen that prime time broadcasting hours are from 20.00 to 23.00 (Morissan, 2008). There are also those who write that prime time for the whole world is 18.00 to 23.00 and in Indonesia itself is 18.00 to 22.00 (Ginting, 2015). The difference in understanding is not too much of a problem because of the six private broadcaster studied, none of them broadcast $30 \%$ of the portion of local programs at prime time. 
The six private broadcaster studied simultaneously broadcast local programs in the broadcast area of Malang City between 00.30 WIB to 07.00 WIB. Unlike other private broadcaster, Metro TV divides the broadcast time of their local programs into two broadcast times, namely at $00.30 \mathrm{WIB}$ to $02.00 \mathrm{WIB}$ and during the day from 13.00 WIB to 14.00 WIB. However, even so, there is no private broadcaster that meets the provisions for the prime time broadcast portion as written in PSS article 68 paragraph 2.

Based on the broadcast time, all private broadcaster simultaneously broadcast local programs at broadcast time divisions called All Other Time (Morissan, 2008). Of all the regulations that became the source of this research, no explanation was found regarding when the $10 \%$ local program broadcast should be done. So that private broadcaster can freely place local programs at any broadcast time, even during the audience's bedtime, as is currently the case.

The next discussion is about information content related to local programs. To understand what is meant by the broadcasting regulator as a local program, it can be seen from the following P3SPS articles:

Local programs are broadcast programs with local content that include journalistic broadcast programs, factual broadcast programs, and non-factual broadcast programs in the context of developing the potential of the local area and are carried out and produced by local regional resources and broadcasting institutions (Indonesian Broadcasting Commission Regulation Number 01/P/ KPI/03/2012 concerning Broadcasting Code of Conduct article 1 paragraph 15).

Local programs are broadcast programs with local content which include journalistic broadcast programs, factual broadcast programs, and non-factual broadcast programs in the context of developing the potential of the local area and are carried out and produced by local regional resources and broadcasting institutions (Regulation of the Indonesian Broadcasting Commission Number 02/P/ KPI/03/2012 concerning Broadcast Program Standards article 1 paragraph 17).

Programmatically, all private broadcaster seem to fulfill the aspect of the type of program that is broadcast in the local broadcast portion. RCTI, Metro TV, and Kompas TV tend to broadcast journalistic programs, so they have new shows on regional information. Meanwhile, ANTV, NET TV, and RTV tend to broadcast feature programs with a timeless concept, which is a program that can be shown repeatedly because it is information that is timeless. Not too much information for the point of "done and produced by local regional broadcasters and resources", because not all shows have a production team that is clearly shown in the credits at the end of the show. There is no information about local broadcasters as part of local program production. All private broadcasters continue to use the name and logo of the central private broadcaster and add regional descriptions below them. 


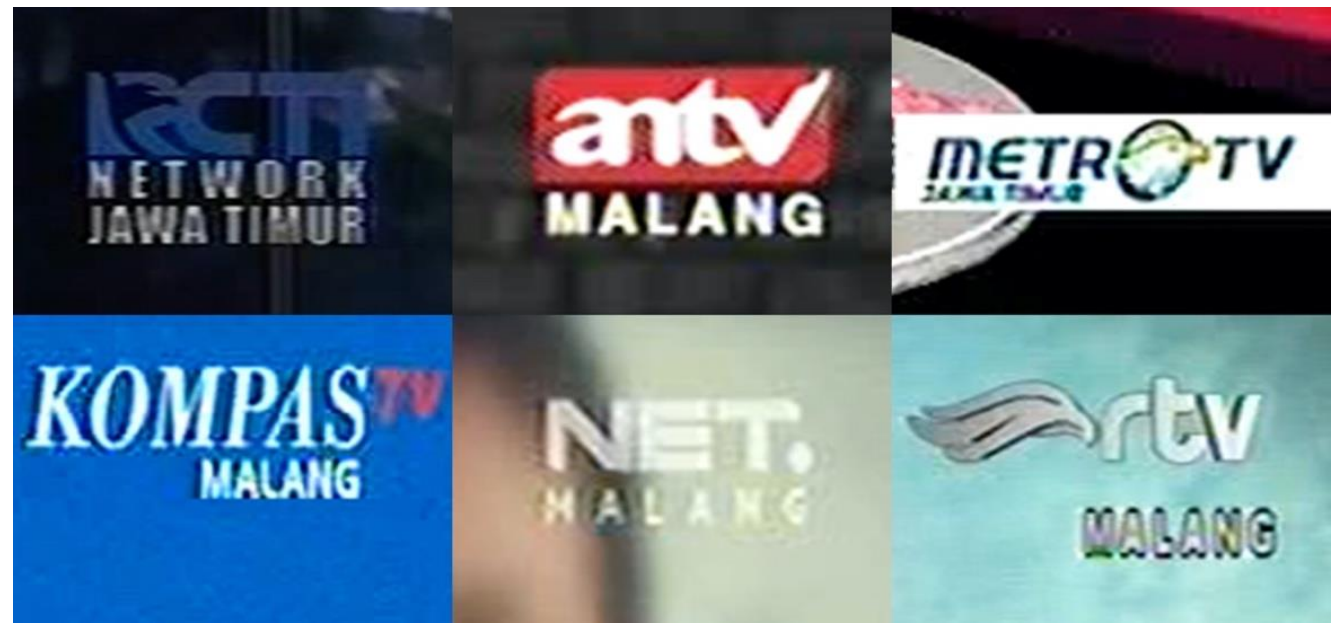

Figure 2. Regional Labels Under the private broadcaster Logo, from Research Documentation (2020)

The journalistic program that is broadcast as a local program is the result of the production of the relevant private broadcaster regional bureau. This can be seen from the information on the credit title which includes the location and contact of the regional bureau. RCTI Surabaya bureau produces programs Around East Java Inews, Metro TV Surabaya bureau produces all local programs that are broadcast, namely East Java Bulletin, Business Bulletin, Morning Journal, Midpoint, and Special Midpoint. As for the Kompas TV news program, there was a collaboration between Kompas TV, Surabaya bureau (which produces Kompas East Java and Kompas East Java Sepekan) and Kompas TV Malang bureau (which produces Kompas Malang).

In contrast to local journalism programs, the feature programs displayed by private broadcaster in this study do not all have information about local content producers that are broadcast. In the Cahaya Hati program in East Java and Panorama in East Java, ANTV stated in the credit title that Malang City only uses transmission, there is no office or bureau. In the Risalah Hati program aired by NET $\mathrm{TV}$, in the credit title section an explanation was given that the program was produced by the NET JATIM Production Team, but the same thing was not found in the Halal Living programs in East Java, Lentera Indonesia East Java, and Indonesia Bagus East Java. RTV does not always display credit titles as additional information on all local programs that are broadcast, but researchers see that there are differences in the content of credit titles in programs. In the Malang program to build the country's potential, the credit title begins with information on the Regional Program Insurer on behalf of Aking Wijang Pambudi, who based on the article from KPI is a representative of RTV Malang. While in the Fun Time and Panorama programs, the credit title does not include information about regional productions and directly includes the production team from the center. For the Frame Hati program from Kompas TV, the researchers did not find any information regarding which bureau produced the program. However, the researcher found running text in the form of information from the resource person with the area code 031 which indicated that it was from Surabaya. The Nusantara Culinary Program and Kompas Nusantara do 
not use credit titles in events like in other programs, but at the end of each segment they directly include the reporter and the location of the segment.

The discussion above shows that the work on local programs broadcast in Malang City is divided into two: work by the center and work by regional bureaus. Examples of workmanship by the center can be seen from the impressions of Lentera Indonesia East Java, Indonesia Bagus East Java, and Halal Living East Java. The three shows have a larger crew list when compared to the Risalah Hati program. Another finding is that Lentera Indonesia, Indonesia Bagus, and Halal Living are series programs that discuss various regions in Indonesia, not only Malang City. Lentera Indonesia and Indonesia Bagus use native speakers from the regions that are broadcast, while Halal Living uses hosts from Jakarta who travel to visit areas in Indonesia.

In relation to program work, the discussion goes into how private broadcasters in Malang City implement the meaning of "local" in the context of information in television programs. For this study, the researchers deliberately divided the program area content into four categories, namely: Malang, outside Malang, East Java, and outside East Java. Malang indicated that the information submitted came from Malang. Outside Malang is information from areas outside Malang but still within the scope of East Java. East Java is information addressed to all citizens of East Java. Outside East Java indicates information originating from areas outside East Java, both nationally and internationally. From the data obtained, most private broadcaster defines local as all regions in East Java. private broadcaster does not only present information from Malang, but also from Surabaya, Jember, Kediri, and several other areas. Meanwhile, for RTV and Kompas TV, the scope of broadcasts has expanded by informing regional shows outside East Java.

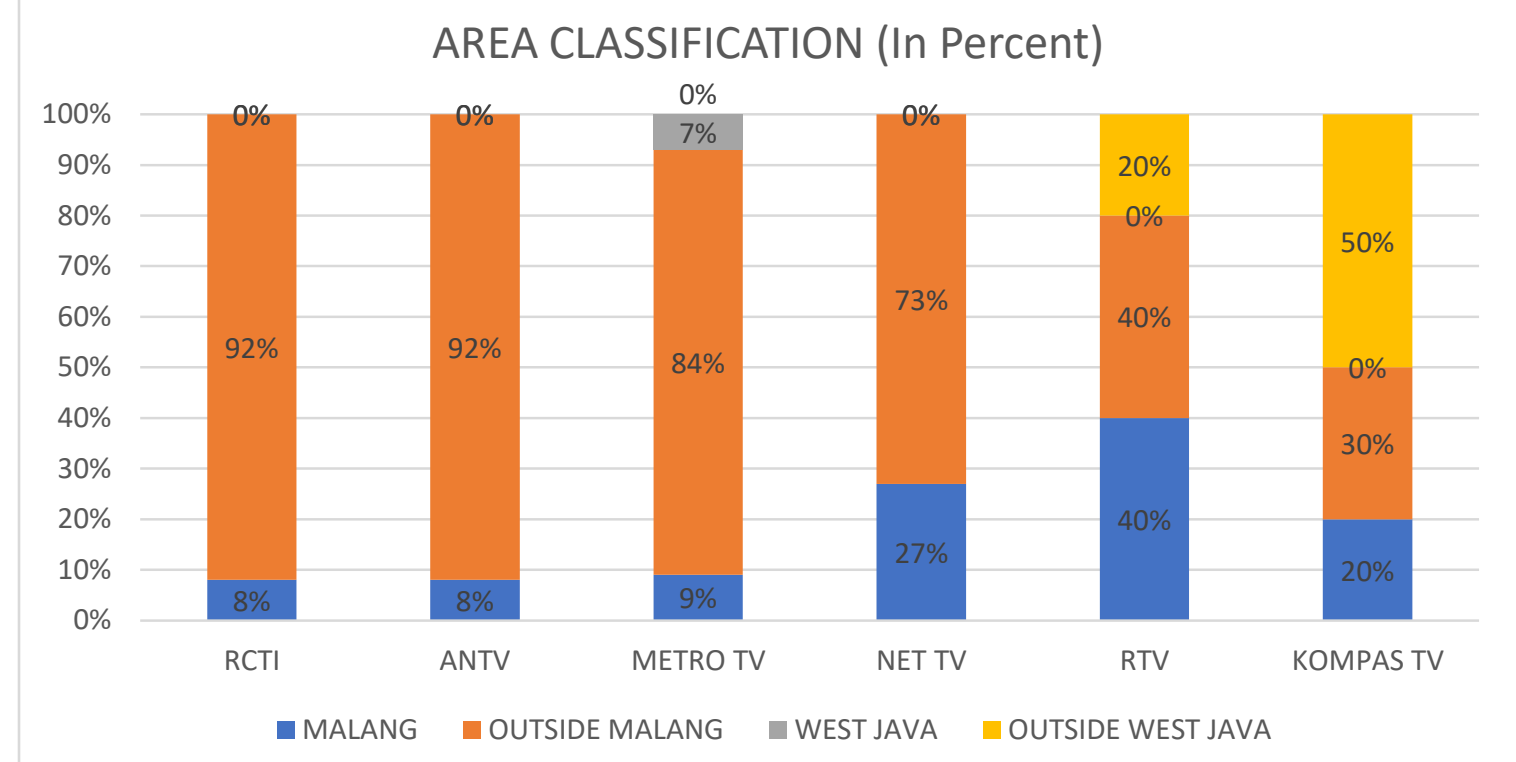

Graph 2. Comparison of Private Broadcaster Regional Reports, from Researcher's Processed Data 
From the chart above, four of the six private broadcasters studied (RCTI, ANTV, METRO TV, NET TV) in this study have the largest portion of information on areas outside Malang within the scope of East Java. RTV has the same portion of information for Malang City and cities outside Malang. Meanwhile, Kompas TV has the largest portion of information content for regions outside East Java. The distribution of the content of the area information that is reported shows how private broadcaster interprets what is called a local program. All private broadcasters simultaneously mean that local is the scope of the province, judging from the variety of information that is displayed. In fact, the provisions regarding the so-called local broadcast area coverage are written in the Government Regulation of the Republic of Indonesia Number 50 of 2005 concerning the Implementation of Private Broadcasting Institutions.

The number of Private Broadcasting Institutions providing radio broadcasting services and/or television broadcasting services within one local broadcasting area shall be stipulated by a Ministerial Regulation based on the radio frequency master plan (Government Regulation of the Republic of Indonesia Number 50 of 2005 concerning Broadcasting Organization of Private Broadcasting Institutions Article 13).

Local broadcasting area coverage is broadcast service area coverage which covers the area around the domicile of the broadcasting institution concerned or within one district/city (Government Regulation of the Republic of Indonesia Number 50 of 2005 concerning Broadcasting Implementation of Private Broadcasting Institutions: Explanation Section on Article 13).

By regulation, what is meant by local is the coverage of the city or district area, so that the implementation of private broadcasters broadcasting local programs in Malang City can be said to be inaccurate. RTV and Kompas TV also provide information on areas outside East Java in the broadcast time of local programs in Malang City, so that it is not in line with the purpose of enacting regulations on local programs themselves. Broadcasting regulations provide an illustration that as much as $10 \%$ of the broadcast portion of local programs should only be filled with information related to the City of Malang. While it can be seen from the data collected, all private broadcasters broadcasting in Malang City understand that what is meant by "local" is the scope of East Java. In addition, researchers conducted additional observations in March 2021 to ascertain whether there was a change in the broadcasting pattern of local programs in Malang City. Based on the data obtained, the pattern as described above still applies. There is even some content that is still broadcasting in 2021. The results of the data collection show that the broadcasting pattern of local programs is still the same as when collecting data in one month in 2020. This means that there is no enforcement of regulations by the East Java KPID regarding non-compliance with private broadcaster implementation on regulations regarding local programs in Malang City.

The economic system for the media also follows the economic system in general. Most countries try to apply the basis of a market economy in the formation 
of a mixed economic system. A mixed economy involves the principles and ideals of a free market, but also applies government regulation and supervision (Albarran, 2010, p. 36). Such a media market system is what Indonesia is trying to realize. Laws and policies are used to address a number of national interests and social policy objectives (Albarran, 2010, p. 111). The importance of the government's role in the media industry in Indonesia is because broadcasting uses a frequency spectrum which incidentally is owned by the public. However, as noted by Albarran (2010), for industry, regulation can limit the profit potential of the business as well as the overall market share. This is reflected in the results of this study. The researcher will share an explanation of two main points of broadcasting regulations which are quite contradictory from a business point of view.

First, SSJ is not doing well. The description of the implementation of the SSJ in broadcasting regulations requires private broadcaster to be affiliated with other regional television stations to expand the broadcast network. This form of affiliation can be mutually beneficial. For the main private broadcasters, program broadcasts can reach a wider audience in various regions. Member stations, which are usually local television stations, receive program supply assistance so as to reduce the cost of producing independent programs. However, it also means that the central private broadcaster must bear the operational and production costs of the member stations themselves. The bureau itself is an important element in the implementation of local program broadcasting because local program regulations are required to use local human resources to produce programs that are more relatable to the local community. In Malang City, of the six private broadcasters broadcasting locally, only Kompas TV has a bureau in Malang City. Kompas TV Malang collaborated with Kompas TV Surabaya to cater for local content broadcasts. Metro TV and RCTI only have bureaus in Surabaya that relay local broadcasts to Malang City via transmission. Meanwhile, NET TV, ANTV, and RTV use transmission without a bureau in Malang City. The absence of regional bureaus eliminates the element of 'production by regional human resources' and results in two types of programs, namely: programs produced from previous years that are broadcast repeatedly and programs made by the central private broadcaster which take place in the area where members' stations are located.

Continuing from the results of these types of programs, it leads to the second point, namely private broadcaster tends to ignore or use as little effort and cost as possible to fulfill local program broadcasting requirements. By regulation regarding the broadcast duration of local programs, several private broadcasters have indeed met this target, by rebroadcasting local programs that had been made several years earlier. That way, private broadcaster will save on program production costs. This situation is carried out by almost all non-news private broadcaster in Malang City. In addition, as explained in the previous sub-chapter, by broadcasting local programs, private broadcaster has the potential to lose $10 \%$ of their potential advertising slots because advertisements broadcast from the center are not relayed to member stations' areas. SSJ can run ideally if member stations can also attract 
regional advertisers and fill the non-relay program slots of the central private broadcaster. Meanwhile, in the field, as the results of this study show, of the 4538 advertisements broadcast during local program breaks, there are only 2 commercial advertisements. From a business perspective, of course, this is a loss.

Gillian Doyle (2011) provides two alternatives in balancing market and state forces. If you look at the current state of Indonesia, the first alternative that Doyle offered can be considered inappropriate because it has the possibility of going back to the pre-reform era, where the government supplied and controlled the media by way of being funded by taxes. The second alternative is to let supply and demand from the market determine the content produced by commercial companies. However, Albarran (2010) views that regulation is still important in building and maintaining competition, to protect workers and consumers. However, what makes broadcasting regulated by regulation is that the government must ensure that what people see on screen reflects the state of society and promotes values and ethics (Salomon, 2009, p. 202). Law Number 32 concerning Broadcasting which has been in effect since 2002 has not changed according to the current situation. KPID as a regulator also gives a lot of tolerance for violations that occur in broadcasting local programs in Malang City, so that local programs no longer carry out their mandate as expected in the spirit of Law of The Republic of Indonesia Number 32 of 2002 on Broadcasting.

\section{CONCLUSION}

The implementation of SSJ as a national broadcasting system in Indonesia has the hope that economically television broadcasting is more equitable because local television stations do not need to be independent stations that finance themselves (Armando, 2011, p. 55). By design, local television stations affiliated with large private broadcaster from Jakarta will be assisted in their broadcasting program by being allowed to broadcast $90 \%$ of programs from the private broadcaster. So that local television stations only need to pay production costs for $10 \%$ of the number of broadcasts in one day. Program production has the biggest cost in the television business, by following the SSJ, it should be very helpful for local television stations and the broadcasting business in Indonesia to develop well in various regions, not only Jakarta. Private broadcaster from Jakarta also benefit from being able to expand its broadcast network to areas resulting from its affiliation with local television stations in these areas.

However, it seems that until this thesis is written, especially in Malang City, there are still difficulties in running a network broadcast system that is truly in accordance with the mandate of Law of The Republic of Indonesia Number 32 of 2002 on Broadcasting. Six of the nine private broadcasters with a main station in the City of Jakarta carry out the same pattern of broadcasting local programs. Unfortunately, the similarities applied by the private broadcasters are different from the regulations written in the broadcasting regulations regarding local programs. Starting from reducing the portion of local program broadcasts, positioning local 
program schedules that are not appropriate, to not broadcasting local programs at all in their daily broadcasts. This study took a sample of impressions in February 2020 and carried out a thorough data collection in August - November 2020, then added to the sample data in March 2021, and resulted in data that did not change much. This explains that with the discrepancies written in the results of this thesis research, there is no action from the broadcasting regulator.

Thus, it is better if the regulations regarding local programs for private broadcasters are abolished and replaced with regulations regarding program content that are even more varied in raising information in regions in Indonesia. Several private broadcasters have tried to make programs that can lift this diversity, such as Net TV with Indonesia Bagus or Trans7 with Jejak Petualang. In terms of news, private broadcaster in Indonesia has also tried to inform news from all over Indonesia through their respective regional contributors. Not to mention when considering the digital era like today, information from various regions can be easily conveyed and disseminated to various circles.

Without realizing it, the current broadcasting regulations are secretly contradicting what is advertised as "diversity of content" and "diversity of ownership". If the government does have "concerns" about meeting the information needs of certain local communities, then the government can provide ease of regulation to local private broadcaster to be able to develop in the Indonesian broadcasting sector. Private broadcaster from Jakarta and local private broadcaster do not have to compete, because the two private institutions have different scopes of information and segmentation. With the current implementation of regulations related to the SSJ, the government has instead provided an opportunity for private broadcaster from Jakarta to strengthen the monopoly side of each private broadcaster. Local stations are transformed into "private broadcaster regional bureaus", not developing with their own station names. For example, in Malang, Kompas TV broadcasts using the CRTV frequency and RTV uses the NDTV broadcast frequency. However, CRTV and NDTV do not have broadcast identities in broadcasting in Malang City, replaced with regional labels on behalf of private broadcaster from Jakarta. Whereas local private broadcaster have the same potential as private broadcaster from Jakarta. The local private broadcaster can inform the situation that is more relatable to the local community and the private broadcaster from Jakarta can continue to broadcast providing information from all over Indonesia, because it cannot be denied, for the entertainment side, people are still loyal to private broadcaster shows from Jakarta.

The history of Indonesia's broadcasting order, particularly with regard to private broadcasting institutions, is carried out in reverse. The first private broadcasting institution to broadcast in Indonesia was Rajawali Citra Televisi (RCTI) in 1987, while the law governing broadcasting was issued in 1997 (Law Number 24 of 1997 concerning Broadcasting). In a span of 20 years, four new private broadcasters have been born in Indonesia, namely: Surya Citra Televisi (1990), TPI (1991), ANTV (1993), and Indosiar (1995). The broadcasting sector in Indonesia itself 
has undergone many changes in the last 18 years. It is time for a revision of Law of The Republic of Indonesia Number 32 of 2002 on Broadcasting. Although the bill circulating on the internet seems to be more concerned with changing from analog or terrestrial broadcasting models to digital broadcasting models, it is also necessary to pay attention to the elements that are sought to realize diversity of content and diversity of ownership. It is hoped that this research can provide a view that what can be done to better understand the field of broadcasting in Indonesia is to see how private broadcasters in Indonesia interpret and implement the regulations that were made after private broadcaster was established.

\section{REFERENCES}

1. Albarran, A. B. (2010). The media economy. In The Media Economy. https://doi.org/10.4324/9780203927717

2. Armando, A. (2011). Televisi Jakarta di atas Indonesia: Kisah Kegagalan Sistem Televisi Berjaringan di Indonesia. In Bentang Pustaka.

3. Armando, A. (2016). Televisi Indonesia Di Bawah Kapitalisme Global.

4. Armando, A. (2019). Kontestasi dan Negosiasi Kepentingan dalam Implementasi Sistem Siaran Jaringan Televisi di Indonesia. Jurnal Komunikasi, 14(1), 41-60. https://doi.org/10.20885/komunikasi.vol14.iss1.art3

5. Creswell, J. W. (2009). Research Design: Qualitative, Quantitative and Mixed Approaches (3rd Edition). In Research Design: Qualitative, Quantitative, and Mixed Methods Approaches. https://doi.org/10.2307/1523157

6. Creswell, J. W., \& Poth, C. N. (2018). Qualitative Inquiry \& Research Design Choosing Among Five Approaches Fourth Edition.

7. Ginting, S. S. (2015). Wajah Tayangan Prime Time Televisi Indonesia: Dimana Kepentingan Publik Di Tempatkan?. Jurnal Ilmiah Komunikasi, 4, 18-41.

8. Government Regulation of the Republic of Indonesia Number 50 of 2005 concerning the Implementation of Broadcasting for Private Broadcasting Institutions

9. Havens, T., \& Lotz, A. D. (2017). Understanding Media Industries (2nd ed.). Oxford University Press.

10. Indonesian Broadcasting Commission Regulation Number 02/P/KPI/03/2012 concerning Broadcast Program Standards.

11. Kurniawan. (2010). Semangat Otonomi dan Kebutuhan Daerah: Kajian terhadap Penyempurnaan UU Nomor 22 Tahun 2009 (Autonomy Spirit and Regional Needs). KANUN, 51.

12. Law of the Republic of Indonesia Number 32 of 2002 on Broadcasting.

13. Lim, M. (2011). @ Crossroads: Democratization $\mathcal{E}$ Corporatization of Media in Indonesia. 1-32.

14. Littlejohn, S., \& Foss, K. (2009). Encyclopedia of Communication Theory. SAGE Publications, Inc. https://doi.org/10.4135/9781412959384

15. Malik, S. (2009). Media Democracy. Society for Alternative Media and Research.

16. Morissan. (2008). Manajemen Media Penyiaran: Strategi Mengelola Radio E Televisi. 
In Manajemen Media Penyiaran: Strategi Mengelola Radio \& Televisi. Kencana.

17. Mughan, A., \& Dumitrescu, D. (2010). Mass Media and Democratic Politics. In K. T. Leicht \& J. C. Jenkins (Eds.), Handbooks of Sociology and Social Research. Springer New York. https://doi.org/10.1007/978-0-387-68930-2

18. Nugroho, H. (2015). Demokrasi dan Demokratisasi: Sebuah Kerangka Konseptual Untuk Memahami Dinamika Sosial-Politik di Indonesia. Jurnal Pemikiran Sosiologi, 1(1), 15. https://doi.org/10.22146/jps.v1i1.23419

19. Nugroho, Y., Putri, D. A., \& Laksmi, S. (2012). Memetakan Lansekap Industri Media Kontemporer di Indonesia. In Centre for Innovation Policy and Governance (CIPG).

20. Regulation of the Indonesian Broadcasting Commission Number 01/P/KPI/03/2012 concerning Guidelines for Broadcasting Conduct.

21. Regulation of the Minister of Communication and Information Technology Number 5 of 2018 concerning Reporting of Changes in Licensing Data, Permit Fees, Network Station Systems, and Economically Developed Regions and Economically Less Developed Regions in the Implementation of Broadcasting.

22. Salomon, E. (2009). The Role of Broadcasting Regulation in Media Literacy. Comunicar, 16(32), 147-156. https://doi.org/10.3916/c32-2009-02-013

23. Siregar, A. E. (2014). Mengawal Demokratisasi Media: Menolak Konsentrasi, Membangun Keberagaman. Kompas. 